\title{
Trade and Migration in an Enlarged European Union: A Spatial Analysis
}

\author{
Justin B. May \\ College of William and Mary
}

\author{
College of William and Mary \\ Department of Economics \\ Working Paper Number 64
}

October 2007

\section{COLLEGE OF WILLIAM AND MARY}

\footnotetext{
* The author would like to thank Jim Levinsohn, Alan Deardorff, Juan Carlos Hallak, Ken Kollman, and participants at: the University of Michigan's Seminar on European Integration, the IREX/WWC Policy Symposium, the ATINER 4th Internatonal Conference, the UACES 36th Annual Conference, and the University of Michigan's Research Seminar in International Economics for invaluable comments and suggestions. All remaining errors are, of course, my own
} 


\title{
DEPARTMENT OF ECONOMICS \\ WORKING PAPER \#64 \\ October 2007
}

\section{Trade and Migration in an Enlarged European Union: A Spatial Analysis}

\begin{abstract}
One of the most prominent features in the evolution of the European Union (EU) has been its geographical expansion. Using a dynamic general equilibrium approach, this paper predicts the effects of future eastward expansions of the EU on both inter- and intra-national flows of trade and labor. Underlying the simulations is a spatial model of the EU incorporating heterogeneous firms, intra-industry trade, iceberg trade costs, and many possible locations. Locations are populated by a large number of potential firms, and these firms employ labor that varies across countries in its relative skill. The dynamics of the model are such that unprofitable firms are forced to exit in the long run, and workers have the opportunity to migrate in response to steep gradients in real compensation. Novel features of the data used here are that locations are defined in a very precise way and that the simulations take as their starting point a proxy for the actual distribution of economic activity across the European landmass. The model is calibrated to match aggregate trade and migration data from the 2004 enlargement as well as data on exporter characteristics. Simulations of enlargement predict an increase in aggregate exports of potential new members to the previous EU-15 of 4.8 percent of GDP in the five-year period following adoption of the acquis communautaire and net migration flows from potential new members to the previous EU-15 of 1.1 percent of aggregate acceding country population over the same period. Moreover, the simulations deliver many of the stylized facts of economic geography.
\end{abstract}

JEL Codes: F12, F15, F16, F22

Keywords: Dynamic General Equilibrium, Enlargement, European Union, Migration, Spatial, Trade

Justin B. May

Department of Economics

College of William and Mary

Williamsburg, VA 23187-8795

jbmay@wm.edu 


\section{INTRODUCTION}

The notion of future expansion, for reasons both political and economic in nature, has been an enduring part of the warp and weft of the European Union. Since the 1951 signing of the Treaty of Paris, which created the first European free trade area, the EU has evolved and expanded both substantively and geographically. ${ }^{2}$ In the intervening 56 years, the European Union has undergone six episodes of geographic expansion and countless expansions of scope. What began as a six-country, three-good free trade area has grown into a common market spanning 27 countries and more than 450 million citizens and embracing the free movement of all goods, services, and factors of production. Among a proper subset of these countries, economic ties have been further strengthened by the creation of a 13-country European Monetary Union.

The addition in May 2004 of ten new member states (NMS-10) to the existing 15-member European Union (EU-15) differed from previous rounds of enlargement in its combination of scope and level of economic prosperity of the accession countries. In terms of both total population and land area, this addition of eight Central and Eastern European nations as well as the Mediterranean islands of Cyprus and Malta was the largest in the history of the Union. The NMS-10 are also noticeably poorer than the previous EU-15. At the time of their entry, the NMS-10 had a combined population of 74 million, or roughly 20 percent of the EU-15's combined population. Despite adding nearly 20 percent to population, however, the new member states contribute just an additional four percent to Union-wide GDP, implying a standard of living far below the previous EU average. Table 1 displays a history of EU enlargements as well as data on their relative size as measured by population and real GDP.

Since 2004, two more Eastern European countries have joined the Union, and six more countries appear likely to accede in the coming years. ${ }^{3}$ Viewed in the aggregate, this expansion to include

\footnotetext{
${ }^{2}$ The Treaty of Paris created the European Coal and Steel Community (ECSC), a free trade area for coal, steel and iron ore, to which Belgium, France, Germany, Italy, Luxembourg, and the Netherlands belonged. The ECSC was the precursor to the European Economic Community (EEC), founded in 1957.

${ }^{3}$ Bulgaria and Romania (the acceding countries) joined in early 2007, while the accession process for Turkey
} 
the two most recent acceding countries (A-2), the two current candidate countries (C-2), and four western Balkan states (WB-4) would be similar in scope to the 2004 enlargement. Like the NMS-10, these eight new members will add roughly 20 percent to EU-wide population, have per capita income around 25 percent of the EU average, and are located on the eastern periphery of the previous EU-15. This enlargement could further shift the economic center of mass in a hypothetical EU-33. Some argue that this shift could create major dislocations as firms gain a new supply of relatively lower wage workers but at the same time are subject to vigorous import competition.

This wide disparity in per capita income along with the location of the NMS-10, A-2, C-2, and WB-4 on the eastern periphery of the previous EU-15 has led some observers to predict significant changes to trade and migration patterns in the coming years. However, competing effects make the magnitude and direction of these changes unclear. Will the previous EU-15 experience an increase in net exports as they take advantage of new markets for their products, or will the addition of lower wage countries mean a flood of cheap imports? Will the result vary by industry characteristics? Should the previous EU-15 states expect massive immigration as workers move in search of higher real wages, or will constraints of language, distance, and familiarity dampen the migration effect of enlargement? Are temporary measures restraining labor flows necessary, or do they simply impede useful redistribution of productive resources?

Because trade between the NMS-10 and the EU-15 was unimpeded for several years prior to their official accession, there are enough data to serve as a guide for the potential effects of further enlargements. Figures 1 and 2 display exports of the NMS-10 countries and NMS-10 aggregate to the EU-15 in the pre-accession period, and Figures 3 and 4 display imports of the NMS-10 countries and NMS-10 aggregate from the EU-15 over the same period. Clearly, the prospect of EU membership (along with the gradual adoption of the acquis communautaire) led to increases

and Croatia (the candidate countries) remains at an earlier stage. The western Balkan states of Albania, Bosnia and Herzegovina, the Former Yugoslav Republic of Macedonia, and Serbia and Montenegro will likely accede much further in the future. 
in trade flows. ${ }^{4}$ Each of the NMS-10 countries experienced an increase in the nominal dollar value of trade with the EU-15, and aggregate trade flows between the NMS-10 and the EU-15 increased nearly four-fold in nominal terms during the 1992-2002 period. Due to strong output growth in the new member states, when measured as a share of GDP the increases in trade between the two groups appear more modest, with exports to the EU-15 rising from 15.8 to 23.0 percent of NMS-10 aggregate GDP and imports from the EU-15 rising from 20.4 to 27.8 percent of NMS-10 aggregate GDP. The trade balance between the two groups was remarkably stable over the period, with the NMS-10 aggregate trade deficit widening by just 0.2 percent of aggregate GDP.

This paper's purpose is to investigate the implications of customs union enlargement for flows of trade and labor in a dynamic general equilibrium setting combining heterogeneous firms, intraindustry trade, and a clear role for geography and space. A novel feature is that this model takes into account the unique geography and pre-existing patterns of economic activity across the European landmass. While the focus of this paper is the experience of European integration, it should be noted that the theoretical framework is applicable to nearly any geographic area, including a featureless plain. Because more and more countries are integrating to form trading arrangements similar to the European example, the techniques employed here could be valuable in a variety of applications. The paper rests at the intersection of three main strains of economic literature - the literature of economic geography, the literature of international trade in the presence of firm-level heterogeneity, and the literature explaining the dynamics of EU enlargement.

Recently, economists have begun to emphasize more frequently the central role of geography in shaping patterns of economic activity. ${ }^{5}$ In literature from gravity models of international trade to recent papers on patterns of development, the role of the spatial distribution of economic ac-

\footnotetext{
${ }^{4}$ The acquis communautaire refers to the total body of EU law. For the purposes of this paper, the provisions with regard to free movement of goods are central. In fact, during the enlargement process, the acquis is broken into chapters for the purposes of negotiation. In every recent enlargement, the chapter covering free movement of goods has been chapter number one.

${ }^{5}$ For a broad survey of spatial models, see Fujita, et al. (1999).
} 
tivity is central. For example, Krugman (1991) demonstrates how individual location decisions by manufacturing firms can shape the location of industry into an industrial core surrounded by an agricultural periphery. Krugman and Venables (1995) develop a model in which, in the presence of declining transport costs, trade in intermediates can lead to changes in real income across nations. Venables (1995) notes that industries are typically less concentrated in Europe than in the U.S. and demonstrates that powerful input-output linkages within industries could lead to a reorganization of industries to a more American pattern as Europe integrates. If linkages are powerful not only within but also across industries, he finds that greater economic integration could lead to a core industrial area which, if labor is not sufficiently mobile, could lead to regional income inequalities. Sachs, et al. (2004) and Redding and Venables (2004) assert the role of physical geography and climate in determining regions' prospects for economic development. Redding and Sturm (2005) examine evidence from pre- and post-reunification Germany and demonstrate that the pre-reunification decline of border cities can be attributed to a lack of market access.

A separate strain of literature examines the impact on trade of firm-level heterogeneity. Bernard and Jensen (1999) document exporter characteristics and find support for the hypothesis that productive firms become exporters and not vice versa. Tybout (2001) provides evidence on the link between heterogeneous firms and the effects of import competition. Eaton and Kortum (2002) construct a Ricardian model with realistic geographic features and employ the model to simulate a number of counterfactual situations including a world free of geographic barriers and countryspecific technology improvements. Bernard, et al. (2003) build a many-country Ricardian model with geographic barriers and imperfect competition. Qualitatively, they are able to match several of the important empirical facts in U.S. plant data. Melitz (2003) demonstrates how, in a world with heterogeneous firms, exposure to international trade can lead to the exit of less productive firms and inter-firm reallocation of resources to yield greater efficiency. Eaton, et al. (2004) create a model that nests both Ricardian and monopolistic competition as special cases and show that this model can match features of French exporting firms. Bernard, et al. (2005) present a hybrid model allowing for both heterogeneous firms as well as country-level differences in endowment and show that trade liberalization leads to a magnification of the effects of comparative advantage. 
Other authors have focused more directly on the European experience. For example, Hoekman and Djankov (1997) and Kaminski (2001) examine the ways in which EU accession has affected trade and foreign direct investment (FDI) flows in Central and Eastern European economies. Hoekman and Djankov focus on describing the magnitude and composition of trade flows between Central and Eastern European economies and the EU and find that those economies that made the transition to a market economy the most rapidly experienced the most significant improvement in export performance during the first half of the 1990s. Similarly, Kaminski finds that those Central European economies that implemented the most liberal reforms benefited most from an increase in FDI. Kohler and Keuschnigg (2000a, 2000b) use dynamic general equilibrium simulations to examine the consequences of enlargement from a public finance perspective.

A small number of authors have attempted to explain the ways in which location decisions change after EU enlargement. For example, Resmini (2003) examines industrial concentration within regions of Bulgaria, Estonia, Hungary, and Romania. She finds that regions that border existing EU members seem to benefit most in terms of industrial concentration. She also finds that regions bordering non-EU, non-candidate countries do not suffer from their very peripheral position as much as economists and policymakers had feared. In general, her results suggest that proximity matters but that distance can be overcome through the presence of a well-developed service sector and solid infrastructure.

Using a dynamic general equilibrium approach incorporating features of the literature on heterogeneous firms as well as the literature on economic geography, this paper focuses on the consequences of the addition of the A-2, C-2, and WB-4 to the European Union. Central among the outcomes are the model's predictions of post-enlargement trade and migration flows. Calibrating to match the aggregate trade and migration results of the 2004 enlargement as well as microeconomic evidence on the relative characteristics of exporting firms, I find that the model predicts an increase in aggregate exports of the eight potential new members to the previous EU-15 of 4.8 percent of GDP and an increase in aggregate imports of the eight potential new members from the previous EU-15 of 5.2 percent of GDP in the five year period following adoption of the acquis 
communautaire. The model also predicts net migration from acceding countries to existing EU members of about 1.1 percent of acceding country population over the same period.

Importantly, the model also delivers many of the stylized facts of economic geography. The law of one price does not hold, and locations further apart are more likely to have price differentials for both factors and goods. Countries' relative productivities vary. Economic interaction decreases with distance. Intra-industry trade makes up an important percentage of overall trade flows. Exporting firms are larger and more productive than those that serve only the domestic market, and firms that locate in densely populated regions tend to be more productive than those that operate at the periphery.

The remainder of the paper is organized as follows: Section 2 explains the theoretical framework. Section 3 describes the simulation methodology and its results. Section 4 concludes and offers policy implications as well as directions for future research.

\section{The Model}

The model outlined below features discrete-time, dynamic elements, and general equilibrium. The theoretical underpinnings of this model draw on the existing literature on international trade in the presence of firm heterogeneity. ${ }^{6}$ The model also incorporates several features common in the spatial economics literature. The landmass occupied by the EU-25 as well as the A-2, C-2, and WB-4 is divided into a matrix of potential sub-national "locations" based on latitude and longitude. Heterogeneous firms at each populated location hire labor supplied perfectly inelastically by agents that are homogeneous within countries but differ across countries in their relative skill. Ultimately, the productivity of a firm depends on the interaction of its firm-specific productivity (think of this as the entrepreneurial skill of its manager) and the skill of the labor available at its location.

Representative consumers at each location purchase goods from a few distinct industries.

\footnotetext{
${ }^{6}$ See, for example, Melitz (2003) and Eaton and Kortum (2002).
} 
Within an industry, each firm's output is perfectly substitutable, so that the firms' output consumed at any location are those that arrive at the lowest c.i.f. price. Across industries, goods are only imperfect substitutes for one another. The equilibrium price of each industry's output in each location is determined by the offer price of the cheapest potential supplier that is unable to supply that location. Because labor is supplied perfectly inelastically, the equilibrium wage at each location is equal to the lowest marginal revenue product of labor of any worker hired.

\subsection{Production}

Goods from each industry can be supplied to any location by a wide variety of firms. ${ }^{7}$ Production requires only one factor, labor, and firm technology is represented by a linear total cost function for a firm $f$ operating at location $j$

$$
t c_{f}=f c_{c j}+f c_{e}+\frac{w_{j} q_{f}}{\phi_{f} \phi_{j}}
$$

Firms face two types of fixed costs. The first fixed cost, $f c_{c j}$, captures the cost of congestion. It is an increasing function of the number of firms in operation at location $j$ (i.e., not latent competitors) and is common to all operating firms firms at that location:

$$
f c_{c j}=\left\{\begin{array}{ll}
0 & \text { if } N_{j} \leq \frac{\sum_{j} N_{j}}{\Gamma} \\
\eta\left[N_{j}-\frac{\sum_{j} N_{j}}{\Gamma}\right] & \text { if } N_{j}>\frac{\sum_{j} N_{j}}{\Gamma}
\end{array},\right.
$$

where $\Gamma$ represents the number of populated locations. That is, firms in locations with more than an average number of operating firms must pay a fixed cost proportional to the amount by which their location exceeds the average. Making the fixed cost dependent on the number of firms operating in a given location is a way of incorporating the pecuniary externality to the firm of locating at a densely populated location. The advantage of being situated at such a location is the potential, at

\footnotetext{
${ }^{7}$ Most of these firms never come into being, as their productivity is too low to allow them to supply any location profitably. Thus, they remain latent competitors.
} 
low transportation cost, to supply a large number of consumers. This fundamental tradeoff between agglomerative and dispersive forces plays a central role in most spatial models. The second fixed cost accounts for the cost of entering the export market. Firms choose to pay this cost in any period in which their expected profit from exporting exceeds $f c_{e}{ }^{8}$

Total productivity is represented as the interaction of firm-specific productivity, $\phi_{f}$, and the productivity of workers at location $j, \phi_{j}$. Firm-specific productivity is drawn from

$$
\phi_{f} \sim N\left(1, \sigma_{\phi_{f}}^{2}\right)
$$

Firms can hire at most the total labor at their location, and as such, a firm's output cannot exceed the output of all labor at its location

$$
q_{f} \leq \phi_{f} \phi_{j} L_{j}
$$

Because labor supply is assumed to be perfectly inelastic within a location, the nominal wage rate at location $j$ is determined by the lowest marginal revenue product of any operating firm located at that location. That is,

$$
w_{j} \equiv \min _{f}\left[M R P L_{f j}\right] \quad \text { s.t. } \quad q_{f j}>0 .
$$

Transport costs are iceberg, linear in distance, and vary by industry. So, in cases in which production occurs outside the consumer's location, $\tau_{j k}=\tau_{k j}>1$ units must be shipped from location $\mathrm{j}$ in order for 1 unit to arrive at location $k$ and

$$
\tau_{j k}=1+\delta_{i} d_{i s t}{ }_{j k}
$$

where $d_{i s t}$ is measured as the diagonal distance (denominated in units of number of locations crossed) between $j$ and $k$. If locations $j$ and $k$ are separated by the border of a customs union, an ad valorem tariff of $t_{j k}$ applies. If locations $j$ and $k$ are separated by a national border, a border effect of $b_{j k}$ applies. The price of industry $i$ 's output at location $k$ is equal to the minimum offer

\footnotetext{
${ }^{8}$ Firms are assumed to know the rate of market exit and use this knowledge to compute their expected profit from exporting.
} 
price of all potential suppliers that do not supply the location. ${ }^{9}$ Thus,

$$
p_{i k}=\min _{f \in i}\left[\frac{\tau_{j k}\left(1+t_{j k}\right)\left(1+b_{j k}\right) w_{j}}{\phi_{f} \phi_{j}}\right] \quad \text { s.t. } \quad q_{f j k}=0 .
$$

Therefore, the profit of firm $f$ located at $j$ producing goods belonging to industry $i$ is

$$
\pi_{f}=\left[\sum_{k} \frac{p_{i k} q_{f j k}}{\tau_{j k}\left(1+t_{j k}\right)\left(1+b_{j k}\right)}\right]-f c_{c j}-f c_{e}-\frac{w_{j} q_{f}}{\phi_{f} \phi_{j}} .
$$

Highly productive firms are able to earn positive profits in this model. The zero-profit condition holds only for the marginal firm.

\subsection{Demand}

The preferences of a representative consumer at location $k$ are given by a constant elasticity of substitution utility function over goods from $I$ discrete industries indexed by $i$

$$
U_{k}=\left[\sum_{i=1}^{I} q_{i k}^{\rho}\right]^{\frac{1}{\rho}}
$$

Goods from each of the industries are imperfect substitutes, so $0<\rho<1$ and the elasticity of substitution between any two industries' output is $\sigma \equiv \frac{1}{1-\rho}>1$. Consumer behavior can thus be modeled as the result of a two-stage process. First, we can consider the set of consumption from all industries as an aggregate good $Q_{k} \equiv U_{k}$ with aggregate price

$$
P_{k}=\left[\sum_{i=1}^{I} p_{i k}^{1-\sigma}\right]^{\frac{1}{1-\sigma}} \text {. }
$$

We can then determine optimal consumption of each industry's output by

$$
q_{i k}=Q_{k}\left(\frac{p_{i}}{P_{k}}\right)^{-\sigma}
$$

This leads to optimal expenditure on each industry's output of

$$
r_{i k}=R_{k}\left(\frac{p_{i}}{P_{k}}\right)^{1-\sigma}
$$

\footnotetext{
${ }^{9}$ Here, the potential supplier is assumed to be located at location $j . j$ need not be different from $k$.
} 
where

$$
R_{k}=P_{k} Q_{k}=\sum_{i=1}^{I} r_{i k} .
$$

Within each industry, the firms' output consumed are those that arrive at the consumer's location at the lowest price, inclusive of transport costs, border costs, and any tariff. Each location $k$ is subject to an aggregate cash-in-advance requirement of the form

$$
R_{k, t+1}=w_{k, t} L_{k, t}+f c_{e k, t}+f c_{c k, t}+\pi_{k, t}+\sum_{i j k} t_{j k} p_{i k, t} q_{i j k, t}+\sum_{i j k} b_{j k} p_{i k, t} q_{i j k, t}
$$

where $w_{k, t}$ is the market-clearing wage at $k$ in the previous period, $L_{k, t}$ is the quantity of labor hired at $k$ in the previous period, $\pi_{k, t}$ is the profits of firms in operation at $k$ in the previous period, the first summation term captures government revenues at location $k$ from tariffs collected by $k$ 's government on imports, and the second summation captures the payment of border costs on goods imported to $k .^{10}$ Because all expenditure is captured in this way,

$$
\sum_{k} R_{k, t}=\sum_{k} R_{k, t+1}
$$

That is, although it can be reallocated to different locations, the sum over all locations of total nominal expenditure is constant over time. Locations are free to import and export without restriction. The model includes no balanced trade condition at either the location or country level.

\subsection{Dynamics}

The model has two dynamic components. One component, by allowing agents to migrate, ensures that total expected real compensation - while not fully equalized across space - does not have an extremely steep gradient. The other component, allowing for the birth and death of new firms, ensures that productive resources are constantly reallocated to their most productive use

\footnotetext{
${ }^{10}$ Note that the model does not allow for any accumulation of assets by agents, nor any sort of equity market. Profits of the firm are distributed in equal measure to all workers at the firm's location as if each firm were owned completely by its employees. Governments serve only to collect tariffs and redistribute them to the location(s) that were responsible for import demand.
} 
and allows for endogenous growth of aggregate real output without population growth. While this model does not allow for economic growth due to population growth or capital accumulation, we may simply consider this to be a detrended version of a model with either or both of these features. Additionally, it should be noted that economic growth does occur in this model as exposure to trade forces inter-firm reallocations of labor.

Within a given location, agents supply labor perfectly inelastically. However, each period, some proportion, $\gamma$, of agents at each location obtain full information on the spatial distribution of expected real compensation. These agents then have the opportunity to move in response to higher expected real compensation elsewhere. Movement of inhabitants from one location to another can be induced by a steep expected real per capita compensation gradient. The difference equation governing the population flow from location $\mathrm{j}$ to location $\mathrm{k}^{*}$ is as follows

$$
\Delta \operatorname{Pop}_{j k, t+1}=\left\{\begin{array}{l}
0 \text { if } \max _{k}\left[\ln \left(\frac{R_{k, t}}{P_{k, t} L_{k, t}}\right)-\ln \left(\frac{R_{j, t}}{P_{j, t} L_{j, t}}\right)-\text { dist }{ }_{j k}\right]-\text { threshold }<0 \\
\gamma \operatorname{Pop}_{j, t} \text { otherwise }
\end{array}\right.
$$

where $k *$ is the location that maximizes the first case of equation (16). A minimum threshold difference in compensation must be met for agents to consider relocating, and the further a new potential location from the agent's present location, the greater the wage differential necessary to induce movement. All agents that choose to emigrate from a given location $j$ become new residents at the same location $k *$. Thus, there is an equation for $\Delta P o p_{k * j, t+1}$ which is simply symmetric to the equation above.

The death of unprofitable firms is governed by a Poisson process of the following form

$$
P(\text { exit })= \begin{cases}0 & \text { if } \pi_{f} \geq 0 \\ \Omega & \text { if } \pi_{f}<0\end{cases}
$$

New potential competitors replace any firms that exit with draws from the (static) distribution of firm productivities. Despite the fact that the productivity distribution is static, aggregate productivity increases can occur as less productive firms exit and labor is reallocated to more 
productive firms. ${ }^{11}$

\section{Data, Calibration, and Results}

\subsection{Data and Timing}

Outcomes of the model are generated by calibration and simulation of various counterfactuals. Novel features of the simulations include the precision with which locations are defined and their initialization with a proxy for economic activity at each location. I begin with data on the spatial distribution of population by latitude and longitude across the 25 current EU members and eight potential members. These data come from individual countries' censuses and cover nearly 50,000 populated places with a minimum of 500 inhabitants. I then map this actual distribution of population into an artificially constructed 82x100 matrix of square "locations" overlaid across the European landmass, correcting for the distortion caused by the curvature of the earth. ${ }^{12}$ In cases in which a location spans a national border, the location is determined to belong to whichever country accounts for the larger percentage of the location's population.

The data capture a large percentage of the 33 countries' combined population. Table 2 presents a country-by-country breakdown of the fraction of actual population that appears in the spatial data. Before calibrating, I adjust the population of each location by a constant factor in order to match the aggregate populations of each country. This ensures that countries are the correct relative size in the simulations. ${ }^{13}$ By taking the product of the country's per capita GDP and the

\footnotetext{
${ }^{11}$ The exit of less productive firms and subsequent reallocation of resources to more productive firms under trade liberalization was found to be an important determinant of aggregate productivity increases in Chile (Pavcnik 2002).

${ }^{12}$ For reference, this makes each location 30 miles square. Because many of the locations are covered by water or are too sparsely populated to measure, only 2522 of the 8200 potential locations are populated.

${ }^{13}$ Adjusting in a linear way implicitly assumes that the census data on population do not systematically ignore citizens in a spatially significant way. To the extent that this assumption is violated, the data used to initialize the simulations do not reflect the actual spatial distribution of population or economic activity. In any case, the adjustment factors for most countries are small.
} 
population at any location, I construct a proxy for each location's initial market potential. ${ }^{14}$ Figure 5 shows a surface plot of the logarithm of this measure of economic activity. The industrial core of Europe, depicted in darker shades and stretching in a wide swath from southeastern England south through Italy, is clearly visible. Despite the fact that taking logs of the data compresses differences, major centers of economic activity (e.g., London, Paris, Madrid, Rome, Athens, and Istanbul) are apparent.

Additional data come from various other sources. I use transformed data on average educational attainment as location-specific productivity. These educational attainment data come from Barro and Lee (2000). Following Caselli (2004), I transform the data into labor productivity differences by assigning 13 percent higher productivity per year of schooling for the first four years of education, 10 percent higher productivity for each of years five through eight, and 7 percent per year for years exceeding eight. Country level data on relative per capita GDP and productivity used to initialize the simulations are shown in Table 3. Trade data come from the International Monetary Fund's Direction of Trade Statistics yearbooks. Data on aggregate population and per capita GDP come from Eurostat. Each simulation covers the eleven year period centered on the year the country joined the customs union, and the model is calibrated to 12 periods per year. ${ }^{15}$ This eleven year period, combined with a three year startup period to initialize the model, mean that each simulation requires 168 periods.

Within periods, the timing of the model is as follows: Goods markets and labor markets clear, determining equilibrium prices, quantities, and wages at each populated location. Wages, profits,

\footnotetext{
${ }^{14}$ Data on per capita GDP at a subnational level would be extremely useful here. However, because of the difficulty of mapping politically defined regions into my locations as well as problems of missing data, it appears infeasible.

${ }^{15}$ Gauging the point at which a country joins the customs union is difficult. A country typically comes into compliance with the acquis communautaire over a transitional period of at least a few years. This period may vary across countries or even across industries (agriculture being a notable example). For the purpose of this paper, a country is determined to have joined the customs union when the Commission of the European Union judges that "significant" progress has been made with regard to that country's compliance with the acquis' provisions on the free movement of goods.
} 
tariffs, and border costs are distributed to inhabitants of each location. Unprofitable firms face a risk of exit. New firms with productivity drawn from the same entrepreneurial productivity distribution replace those that exit. Labor moves in response to steep real compensation gradients. The total compensation at a location becomes that location's total expenditure on goods in the following period.

\subsection{Calibration}

I begin each simulation by populating the locations with roughly 10,000 potential firms from each of four distinct industries. The initial distribution of firms across space is directly proportional to population at each location - as if a certain percentage of the population possesses entrepreneurial skill. Each potential firm is completely described by just four pieces of information: an industry, an entrepreneurial productivity, a latitude, and a longitude. Locations also have four characteristics: a country, a population, a per capita GDP, and a location-specific productivity. At the outset, each firm is potential in the sense that it will not enter the market unless it is able to supply its output to some location. Industries vary in their transportation costs only. However, the model could easily accommodate variation across industries in fixed costs costs of export, fixed costs of congestion, average productivity, border effects, etc. One industry is virtually nontraded (but tradable) because its transportation cost is equal to the marginal cost of the good for each unit of distance traveled. A second industry is transported costlessly. The remaining two industries have strictly positive transport costs, though below the cost of the nontraded sector. Each location must have at least one firm in the nontraded sector.

I calibrate the model to match four key pieces of data: the aggregate increase in exports of the NMS-10 to the EU-15 from the five years prior to the adoption of the acquis communautaire to the five years post-adoption, the aggregate net migration from the NMS-10 to the three countries with

policies of unrestricted immigration, the overall openness of the EU-25 economies in the year of 
adoption, and the percentage of firms that export in the data. ${ }^{16}$ Calibrating to these four features of the data determines four parameters of the model: the tariff rate, the rate at which agents become aware of the spatial distribution of compensation, the border effect, and the fixed cost of export. Table 4 reflects the success of the calibration to each of the above features of the data. I then validate this calibration against the country-by-country increases in exports from the NMS-10 to the EU-15 as well as microeconomic data on exporter characteristics and data on average trade costs.

Validation of the calibration suggests that the model does, indeed, have predictive power. Table 5 displays the predicted country-by-country increases in trade flows based on the above calibration. The model generates a qualitative match; the predicted results show the general pattern of export growth observed during the accession process. In both the data and the calibrated output of the model, the Czech Republic, Estonia, Hungary, Slovakia, and Slovenia experience a rapid expansion in the share of GDP exported to the EU-15. Cyprus and Poland experience a more moderate expansion, while Latvia, Lithuania, and Malta experience a contraction of the share of GDP exported to the EU-15.

Table 6 validates the calibration against three additional firm level exporter characteristics from Bernard, et al. (2003): exporter productivity relative to average firm productivity, exporter size relative to average firm size, and the percentage of total output accounted for by exporters. Average trade costs are also compared to those found by Anderson and va Wincoop (2004). Data in the right column of Table 6 come from Bernard, et al. (2003) and reflect characteristics of exporting plants observed in U.S. data. The left column of the table shows this model's outcomes along the same dimensions. Again the model yields a qualitative match. Exporting firms are a distinct minority, yet they account for a disproportionate share of total output. Not surprisingly, they are larger and more productive than their non-exporting counterparts. In these simulations of

\footnotetext{
${ }^{16}$ Because 1997 was the year in which the majority of the NMS-10 came into compliance with the acquis 'provisions on the free movement of goods, I calibrate to the aggregate increase in exports from the 1992-1996 period to the 1998-2002 period. Ireland, Sweden, and the UK each allow unrestricted migration from the NMS-10.
} 
the European economy, however, exporters are not nearly as different from non-exporters in terms of size and productivity as they are in the U.S. data. This may not be surprising given that Europe as a whole is far more open than the U.S., and the distances goods must travel to become exports are often much smaller. This combination of a history of openness as well as smaller transport costs may lead to a lower bar for exporters to hurdle and, in turn, lead to exporters with characteristics less distinct from their non-exporting counterparts. Average trade costs are found to be 48 percent of marginal cost. While this is considerably lower than the 74 percent figure for worldwide trade data found by Anderson and van Wincoop (2004), the difference can reasonably be attributed to the fact that this study considers only intra-European trade flows whereas theirs examines worldwide trade. Viewed in this light, the 48 percent figure seems reasonable.

Parameters of the model are listed in Table 7. A $\rho$ of 0.75 leads to an elasticity of substitution between any two industries of four, and a $\sigma_{\phi_{f}}^{2}$ of 0.5 implies that the standard deviation of firmspecific productivity is 71 percent. Transportation costs per unit of distance range from 100 percent of marginal cost to zero across the four industries. The two industries with mid-range transport costs are set such that to transport a unit of output across the entire 100-unit width of Europe adds 10 percent and 1 percent to marginal cost, respectively. The value of $\Omega$ is set such that unprofitable firms are forced to exit, on average, after six months. The value of $\theta$ is set such that, in order to induce movement, a real wage must be at least one percent higher for every thirty miles more distant a potential job offer is from the agent's current location, and the minimum differential in real compensation required to induce movement is set to 10 percent.

Values of the calibrated parameters fit with generally held priors. The calibrated pre-accession tariff level is approximately 26 percent. This is significantly higher than actual pre-accession tariff rates, but in the model, tariff reduction stands in for all effects of customs union membershiplowering of tariffs, harmonization of product standards, decrease in time spent clearing customs, etc. The fraction of the population that searches outside of their current location in any given period for higher real compensation, $\gamma$, is calibrated to 0.0136 . This implies a 50 percent chance of willingness to move a distance greater than thirty miles in any ten year period. As in most 
models of trade, border effects are considerable at 31 percent of marginal cost. Finally, a fixed cost of export of 720 per period is necessary to limit the number of firms choosing to enter the export market. ${ }^{17}$

\subsection{Results}

Results of the model are obtained by simulating three counterfactuals - the addition to the EU of the acceding countries (Bulgaria and Romania), the addition to the EU of the candidate countries (Croatia and Turkey), and the addition to the EU of four Western Balkan states (Albania, Bosnia and Herzegovina, FYROM, and Serbia and Montenegro). In each case, the countries likely to have acceded in the past are assumed to be EU members. Thus, Croatia and Turkey join an EU-27, while the WB-4 join an EU-29. The variables of greatest interest are the trade and migration flows between acceding countries and the previous EU-15. Table 8 shows predicted changes in accession country exports to the previous EU-15 as a percent of accession country GDP during years 1, 3, and 5 post-accession as well as a 1-5 year aggregate change.

Exports from acceding countries to the previous EU-15 universally rise as a share of GDP in the first year following accession. Interestingly, though, the initial response often overshoots the long run result, with the maximum increase coming one to three years post-accession. Smaller increases or even decreases in the share of GDP exported to the previous EU-15 are often recorded in years further from accession. Part of this may be due to the fact that the model makes no allowance for the development of an export strategy, creation of distribution channels, brand recognition, or many of other factors that may initially slow a firm's ability to access new export markets.

Overall, exports to the previous EU-15 from the eight likely new member states rise by 4.8 percent of the new members' GDP in the five years following their inclusion in the customs union. The strongest growth is recorded in Turkey and Albania. Bosnia and Herzegovina and FYROM experience more moderate export growth, while Bulgaria, Romania, Croatia, and Serbia and Mon-

\footnotetext{
${ }^{17}$ The numeraire here is median monthly real compensation for the EU.
} 
tenegro experience a decline in exports to the EU as a share of GDP. At first blush, declines in exports of new members to the previous EU-15 might seem improbable. It is worthy of note, however, that EU membership reduces barriers between the acceding countries and the NMS-10 and among the acceding countries themselves. Because the NMS-10 and the other acceding countries are geographically advantaged with respect to trade with the new potential members, it should not be surprising that this may displace trade with the previous EU-15. As was the case in the accession of the NMS-10, the model predicts that net exports of the acceding countries fall slightly as the availability of exports from the EU-15 trumps the increase in new members' exports to the EU. In this case, aggregate net exports fall by 0.4 percent of aggregate acceding country GDP, a figure very close to the 0.2 percent fall experienced by the NMS- 10 .

Table 9 shows predicted accession country emigration to the previous EU-15 during the five years post-accession. Overall, the model predicts emigration from the new members to the EU15 on the order of 1.4 million or roughly 1.1 percent of the acceding countries' population. Not surprisingly, low-wage countries nearer to EU-15 members, like Albania, experience a higher degree of emigration. However, this model does not take into account transitional measures that impede population movement, and so these results are best interpreted as long run (i.e., post-transitional) outcomes. ${ }^{18}$ On an intra-national basis, the model predicts continuing urbanization of Europe as workers migrate to industrial centers. Agents in the potential new members also feel the pull of the industrial core of Europe, with centers of mass of the population distribution tending to move slightly westward post-accession as those locations gain a small locational advantage.

The model also generates many of the predictions common to models of economic geography. Economic interaction is a decreasing function of the distance between any two agents. Over the course of a typical 11-year simulation, roughly 94 million transactions take place, not counting distributions of wages, profits, tariffs, and border costs. The modal transaction in the model occurs

\footnotetext{
${ }^{18}$ At this time, only three countries (Ireland, Sweden, and the UK) are accepting immigrants from the NMS-10 states without restriction. It is likely that similar restrictions on immigration will be in place at the time of accession of the eight likely future members
} 
at a distance of less than 200 miles between producer and consumer, and the dropoff in number of transactions recorded by distance is steep (see Figure 6).

Also, the law of one price fails to hold, with price differentials generally increasing in distance. Figure 7 plots log price differentials by distance for each of four industries, the price index, and the wage. As expected, real compensation and the price index are not fully equalized across space, and the higher the trade costs for a given industry, the less price convergence over distance. Interestingly, while the overall trend suggests that locations further from each other have, on average, larger price differentials for both output and factors, there is a noticeable dropoff in the differential at around 3000 miles of separation for all of the relatively free-moving goods. This dropoff can plausibly be explained by the fact that very few locations in the simulations are separated by a distance this great, and those that are are certainly on Europe's periphery. Thus, it should not be surprising that prices might be more similar between these places than between the core and the periphery. Also, though it is not shown on the figure, EU enlargement decreases price dispersion over space, especially across the border between acceding countries and previous member states.

Finally, as predicted by theory, congestion costs ensure that only the most productive firms are capable of producing in densely populated areas. Figure 8 presents a scatter plot of the logged productivities of all active firms against the log of population at their location. The positive correlation is obvious, with the slope of the best fit line suggesting that a one percent increase in a location's population results, on average, in its firms being 0.15 percent more productive in equilibrium.

\section{Conclusions, Policy Implications, and Directions for Further Research}

With the gradual lowering of barriers and the proliferation of customs unions and other multilateral trade agreements, there is a need for models capable of addressing the dynamic and steady state responses of trade and labor flows to any policy change. The model presented above seeks to address that need. And just as the central features of trade and migration are that they move goods 
and factors from "here" to "there," the central feature of the model is its treatment of distance and space.

The premise of this paper is to investigate how far a relatively parsimonious, spatial model of trade and migration can go toward matching the effects of customs union enlargement. Despite omitting myriad conventional explanations of trade from the model-comparative advantage, resource endowments (other than the labor force), historical trading relationships, cultural similarities, etc.- the calibrated model qualitatively matches the results of the 2004 enlargement as well as micro-level data on exporter characteristics. A model of this sort could be extremely useful to policymakers; it is analytically tractable, easy to simulate, and offers clear policy implications. If policymakers can accurately predict the regions and industries most likely to be profoundly affected by enlargement, then they can better target mechanisms to minimize adjustment costs in those regions and industries. At the same time, they can leave other, minimally affected, regions and industries unregulated at the time of enlargement.

Future versions of the model could include several additional features. Modeling foreign direct investment or allowing for firm movement would make the model more realistic. In the current version of the model, industrial expansion or contraction occurs endogenously across space but only as a result of the birth and death of firms. There is no explicit provision for firm movement. Another important improvement would be to calibrate the model to match greater evidence on bilateral migration flows, but problems of undocumented workers, irreconcilable differences in data collection, and scarcity of available data make this a daunting task. Industries in the model could be more finely mapped into actual industries - differing in their production functions as well as their transport costs. Finally, and perhaps most importantly, spatial models of this sort could be used to simulate other types of policy events in other regions of the world. 
Table 1. Comparison of Previous EU Enlargements

\begin{tabular}{ccccc}
\hline \hline Country & $\begin{array}{c}\text { GDP (Billions } \\
\text { of 1995 Euro) }\end{array}$ & $\begin{array}{c}\text { Percent of } \\
\text { Existing EU }\end{array}$ & $\begin{array}{c}\text { Population } \\
\text { (Millions) }\end{array}$ & $\begin{array}{c}\text { Percent of } \\
\text { Existing EU }\end{array}$ \\
\hline
\end{tabular}

1973 Enlargement

Denmark

98.2

$\begin{array}{ll}. . & 5.0\end{array}$

2.4

Ireland

..

3.1

1.5

United Kingdom

573.0

..

56.2

26.8

TOTAL

..

64.3

30.7

1981 Enlargement

Greece

77.7

9.8

3.5

1986 Enlargement

Portugal

$\begin{array}{rrrr}. . & . . & 10.0 & 3.5 \\ 343.6 & . . & 38.5 & 13.3 \\ . . & . . & \mathbf{4 8 . 6} & \mathbf{1 6 . 8}\end{array}$

TOTAL

183.2

100.1

3.0

7.9

2.3

Finland

189.7

1.6

5.1

1.5

Sweden

3.1

8.8

2.5

TOTAL

473.1

7.7

21.9

6.3

2004 Enlargement

Cyprus

Czech Republic

Estonia

Hungary

Latvia

Lithuania

Malta

Poland

Slovakia

Slovenia
9.5

51.0

4.9

47.9

6.5

8.0

3.1

149.5

21.3

21.5
0.1

0.6

0.1

0.6

0.1

0.1

0.0

1.9

0.3

0.3
0.7

10.2

1.4

10.1

2.3

3.5

0.4

38.2

5.4

2.0
0.2

2.7

0.4

2.7

0.6

0.9

0.1

10.1

1.4

0.5 
Table 1-Continued

\begin{tabular}{|c|c|c|c|c|}
\hline Country & $\begin{array}{l}\text { GDP (Billions } \\
\text { of } 1995 \text { Euro) }\end{array}$ & $\begin{array}{l}\text { Percent of } \\
\text { Existing EU }\end{array}$ & $\begin{array}{c}\text { Population } \\
\text { (Millions) }\end{array}$ & $\begin{array}{c}\text { Percent of } \\
\text { Existing EU }\end{array}$ \\
\hline TOTAL & 323.2 & 4.0 & 74.2 & 19.7 \\
\hline \multicolumn{5}{|l|}{ Acceding Countries } \\
\hline Bulgaria & 12.8 & 0.1 & 7.8 & 1.7 \\
\hline Romania & 35.6 & 0.4 & 21.7 & 4.8 \\
\hline TOTAL & 48.4 & 0.6 & 29.6 & 6.6 \\
\hline \multicolumn{5}{|l|}{ Candidate Countries } \\
\hline Croatia & 21.9 & 0.2 & 4.5 & 0.9 \\
\hline Turkey & 197.4 & 2.2 & 70.7 & 14.7 \\
\hline TOTAL & 219.4 & 2.5 & 75.2 & 15.6 \\
\hline \multicolumn{5}{|l|}{ Western Balkans } \\
\hline Albania & 5.0 & 0.1 & 3.4 & 0.6 \\
\hline Bosnia and Herzegovina & 5.9 & 0.1 & 3.6 & 0.6 \\
\hline FYROM & 4.3 & 0.0 & 2.0 & 0.4 \\
\hline Serbia and Montenegro & 15.5 & 0.2 & 9.4 & 1.7 \\
\hline TOTAL & 30.7 & 0.3 & 18.4 & 3.3 \\
\hline
\end{tabular}

Note. - Data come from Eurostat and, in the case of past enlargements, represent the values of GDP and population in the year of enlargement. Data for future enlargements are the most recent available. 

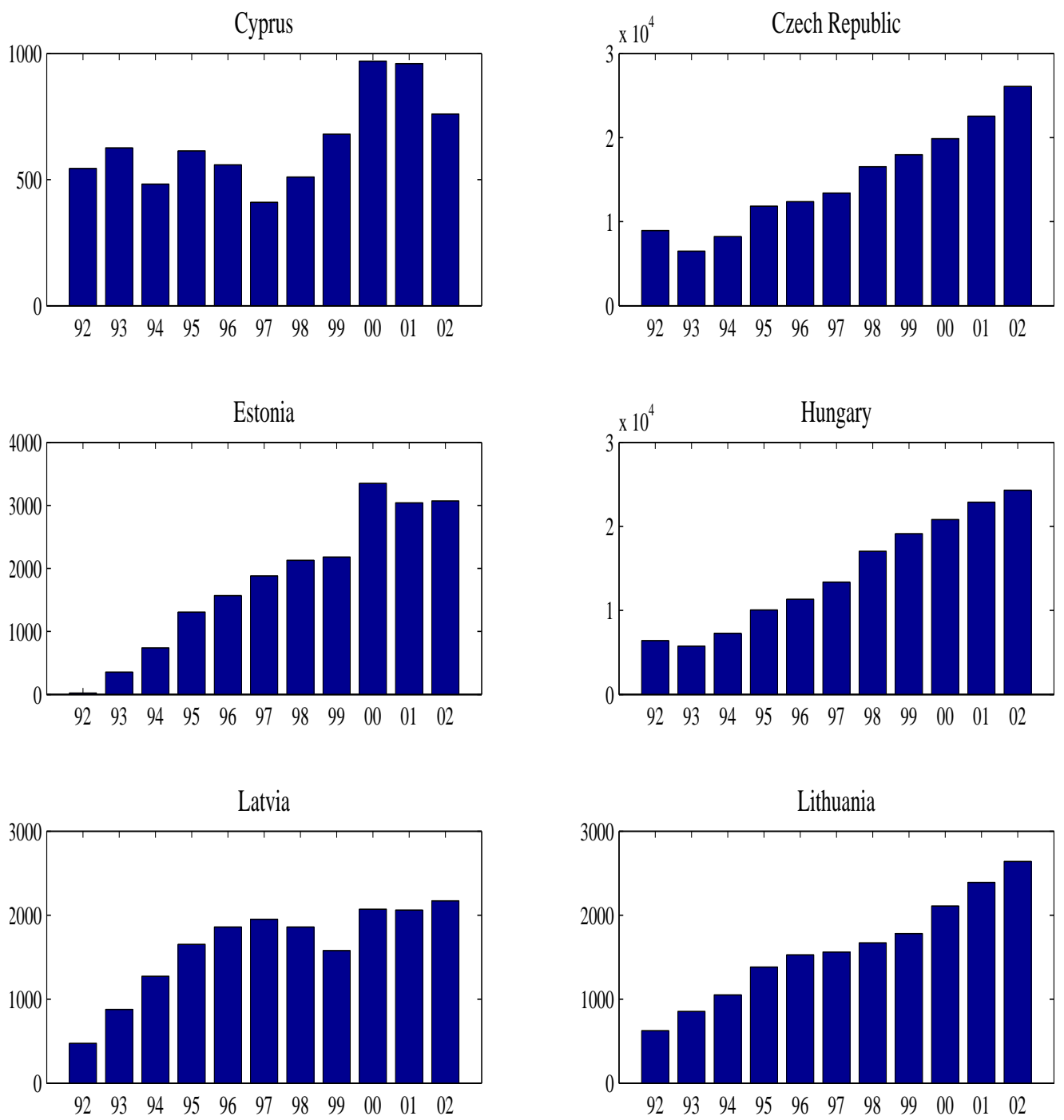

Fig. 1.- Exports of NMS-10 to EU-15 1992-2002 (USD Millions) 

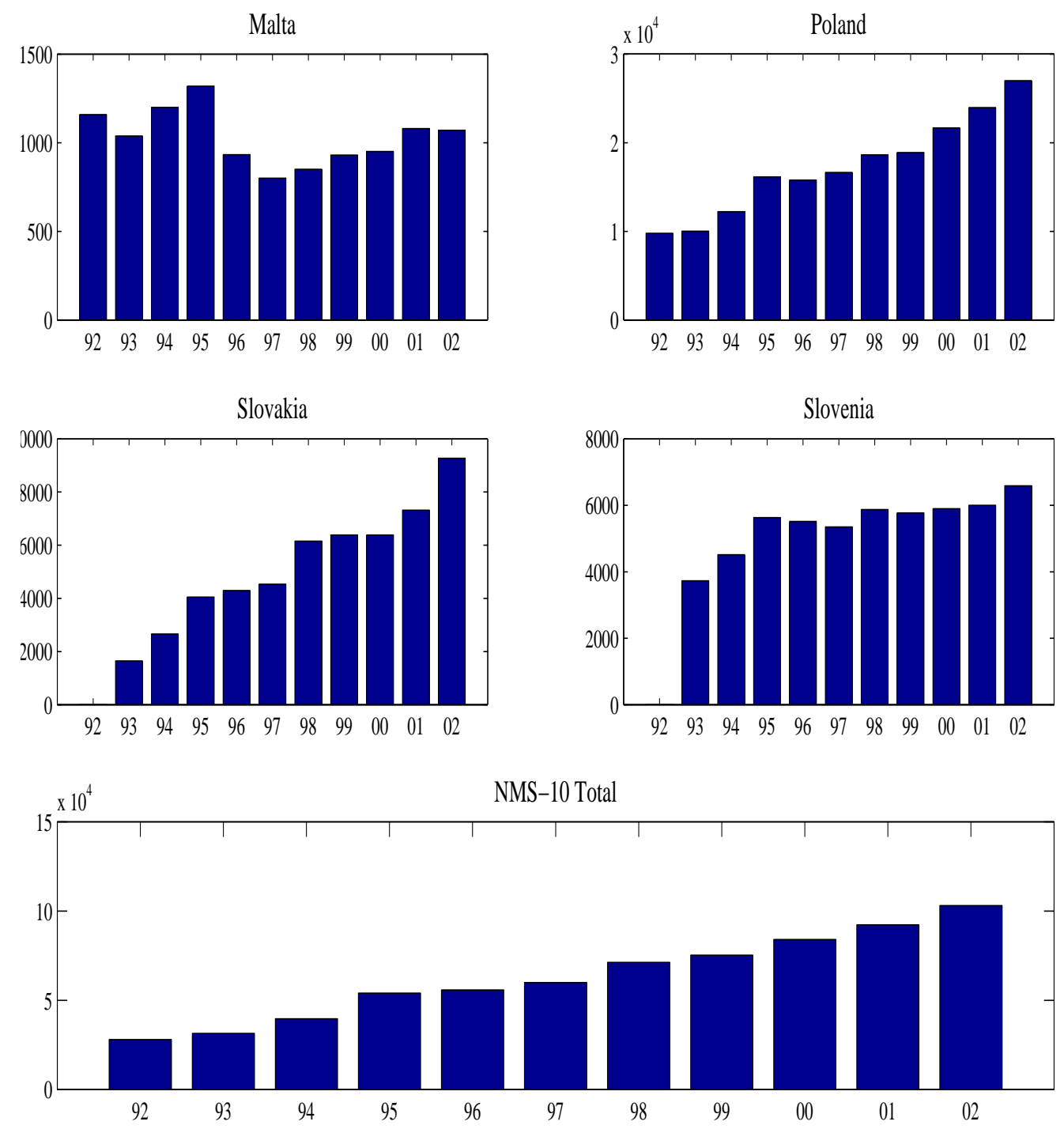

Fig. 2.- Exports of NMS-10 to EU-15 1992-2002 (USD Millions) 

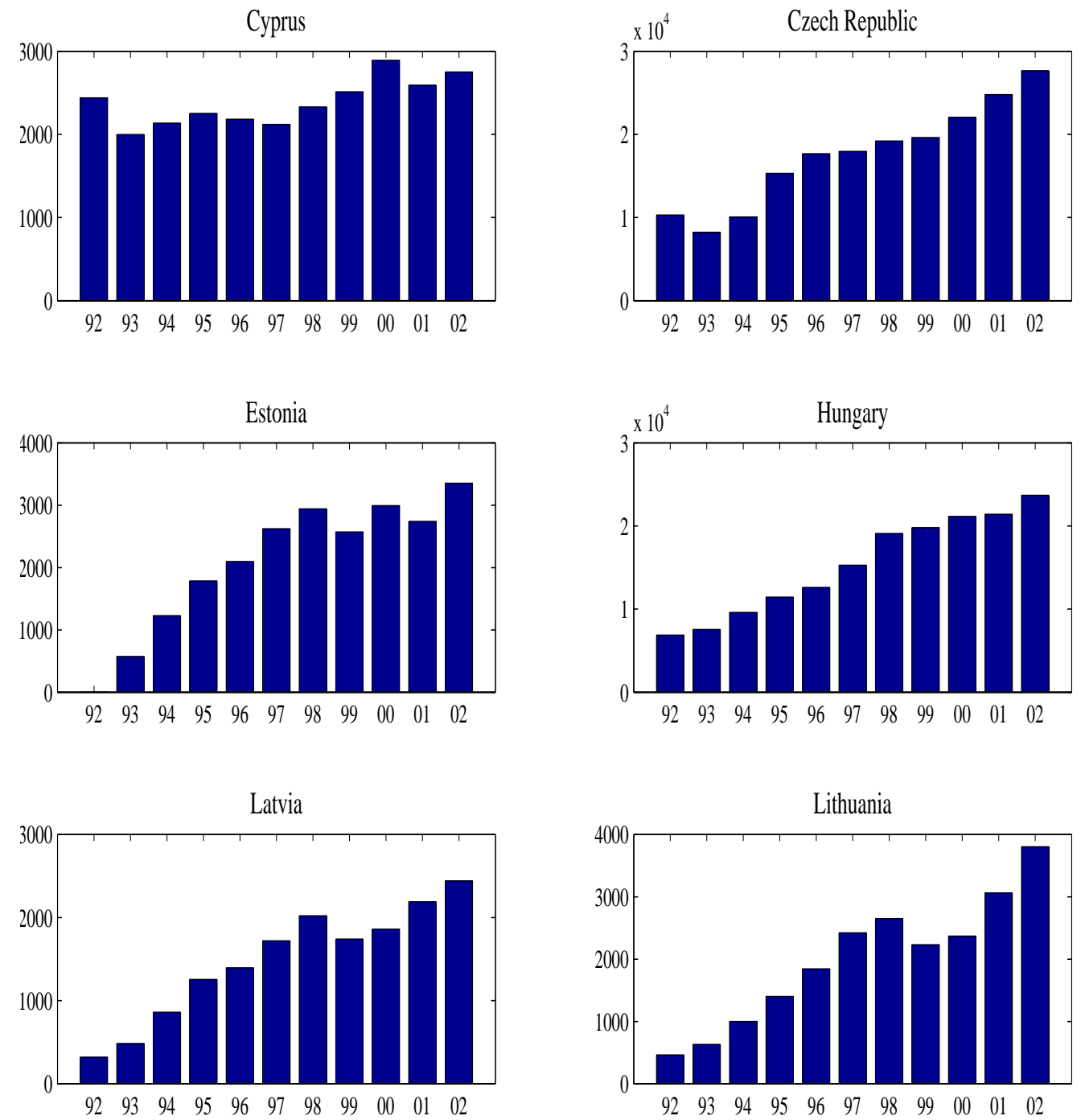

Fig. 3.- Imports of NMS-10 from EU-15 1992-2002 (USD Millions) 

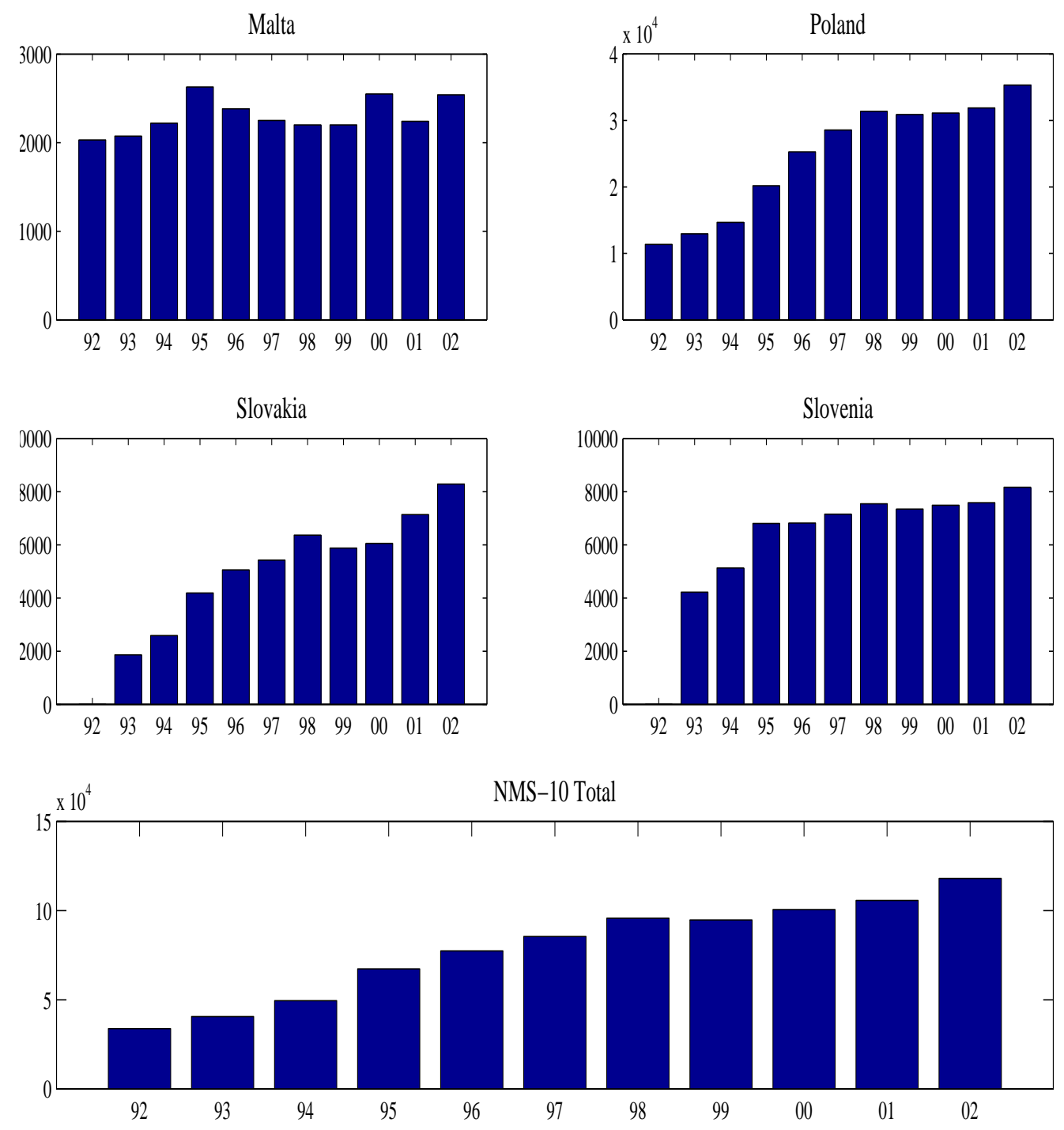

Fig. 4. - Imports of NMS-10 from EU-15 1992-2002 (USD Millions) 
Table 2. Population Coverage (Millions, 2001 Census, Except Where Indicated)

\begin{tabular}{|c|c|c|c|}
\hline Country & $\begin{array}{c}\text { Actual } \\
\text { Population }\end{array}$ & $\begin{array}{c}\text { Data } \\
\text { Coverage }\end{array}$ & $\begin{array}{l}\text { Percent } \\
\text { Coverage }\end{array}$ \\
\hline Albania & 3.36 & 1.26 & 37.5 \\
\hline Austria & 8.04 & 6.30 & 78.4 \\
\hline Belgium & 10.18 & 8.42 & 82.7 \\
\hline Bosnia and Herzegovina & 3.64 & 2.29 & 62.9 \\
\hline Bulgaria & 7.91 & 6.20 & 78.4 \\
\hline Croatia & 4.44 & 3.59 & 80.9 \\
\hline Cyprus & 0.68 & 0.39 & 57.4 \\
\hline Czech Republic & 10.14 & 7.65 & 75.4 \\
\hline Denmark & 5.28 & 6.07 & 115.0 \\
\hline Estonia & 1.36 & 1.85 & 136.0 \\
\hline Finland & 5.12 & 7.87 & 153.7 \\
\hline France & 58.51 & 37.87 & 64.7 \\
\hline FYROM & 2.03 & 1.18 & 58.1 \\
\hline Germany & 82.35 & 63.04 & 76.6 \\
\hline Greece & 10.81 & 9.07 & 83.9 \\
\hline Hungary & 10.09 & 7.73 & 76.6 \\
\hline Ireland & 3.80 & 3.35 & 88.2 \\
\hline Italy & 56.98 & 27.71 & 48.6 \\
\hline Latvia & 2.35 & 2.36 & 100.4 \\
\hline Lithuania & 3.45 & 3.59 & 104.1 \\
\hline Luxembourg & 0.41 & 0.41 & 100.0 \\
\hline Malta & 0.39 & 0.03 & 7.7 \\
\hline Netherlands & 15.78 & 14.91 & 94.5 \\
\hline Poland & 37.88 & 33.24 & 87.8 \\
\hline Portugal & 10.22 & 4.68 & 45.8 \\
\hline Romania & 21.85 & 12.56 & 57.5 \\
\hline Serbia and Montenegro & 10.65 & 6.25 & 58.7 \\
\hline Slovakia & 5.38 & 4.42 & 82.2 \\
\hline Slovenia & 1.95 & 2.33 & 119.5 \\
\hline Spain & 40.25 & 24.44 & 60.7 \\
\hline Sweden & 8.79 & 9.39 & 106.8 \\
\hline
\end{tabular}


Table 2-Continued

\begin{tabular}{lrrr}
\hline \hline \multicolumn{1}{c}{ Country } & $\begin{array}{c}\text { Actual } \\
\text { Population }\end{array}$ & $\begin{array}{c}\text { Data } \\
\text { Coverage }\end{array}$ & $\begin{array}{c}\text { Percent } \\
\text { Coverage }\end{array}$ \\
\hline Turkey & 70.43 & 38.30 & 54.4 \\
United Kingdom & 58.78 & 50.37 & 85.7 \\
TOTAL & $\mathbf{5 7 3 . 2 8}$ & $\mathbf{4 0 9 . 1 0}$ & $\mathbf{7 1 . 4}$ \\
\hline
\end{tabular}

Note. - In most cases data come from the 2001 national level census. Data for Albania, Austria, Bosnia and Herzegovina, Bulgaria, Croatia, Estonia, FYROM, Germany, Italy, Malta, Romania, Serbia and Montenegro, Slovakia, and Turkey come from individual countries' national statistical offices. Data for Bosnia and Herzegovina are from 1997. Data for Albania are from 1998. Data from Turkey are from 2003. 

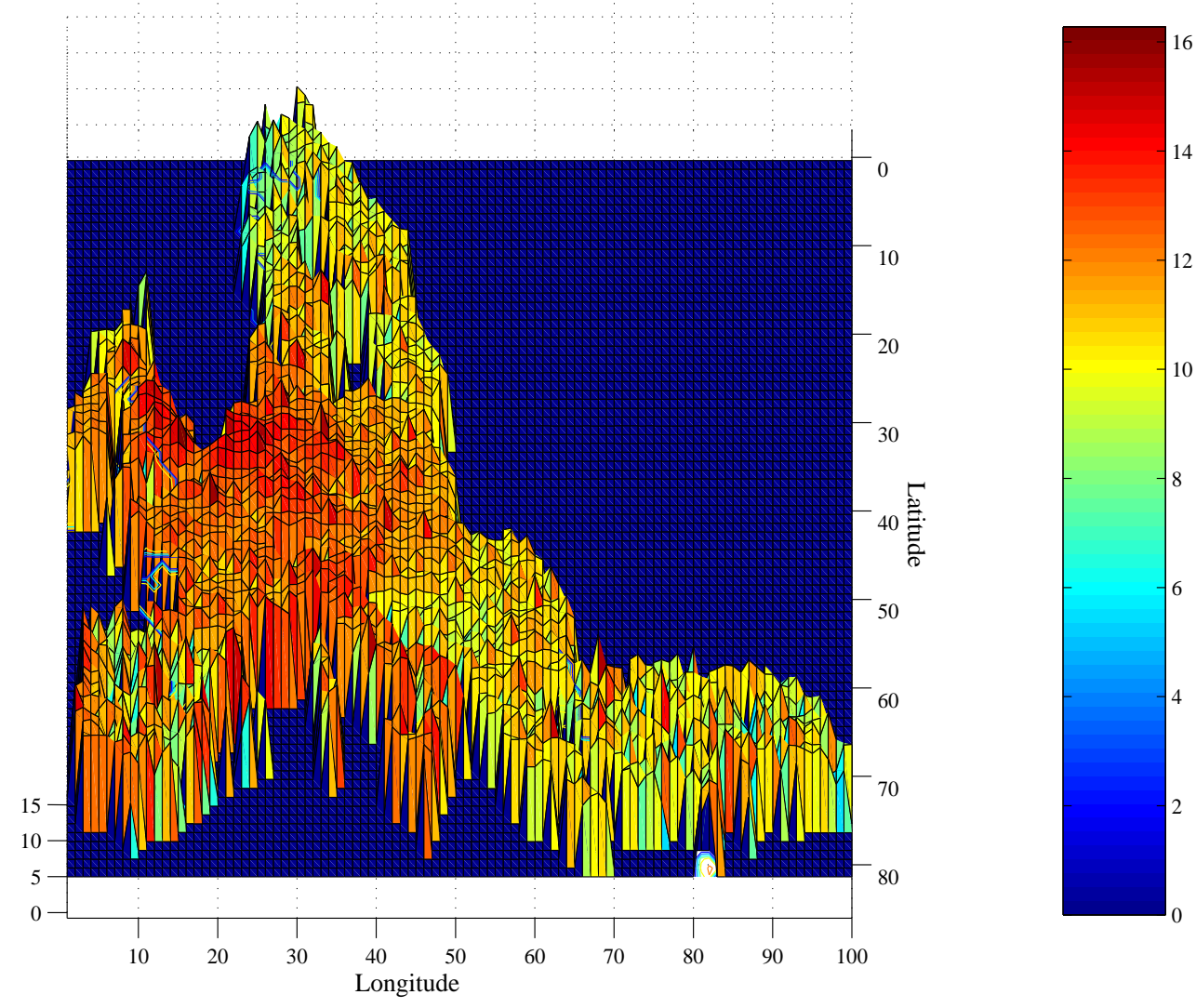

Fig. 5.- Surface Map of Log Economic Activity 
Table 3. Initial Levels of Per Capita GDP and Productivity (Median EU=1)

\begin{tabular}{|c|c|c|}
\hline Country & PCGDP & Productivity \\
\hline Albania & 0.17 & 0.95 \\
\hline Austria & 1.20 & 1.02 \\
\hline Belgium & 1.10 & 1.02 \\
\hline Bosnia and Herzegovina & 0.14 & 0.93 \\
\hline Bulgaria & 0.32 & 1.09 \\
\hline Croatia & 0.40 & 0.84 \\
\hline Cyprus & 0.91 & 1.02 \\
\hline Czech Republic & 0.61 & 1.07 \\
\hline Denmark & 1.24 & 1.11 \\
\hline Estonia & 0.44 & 1.05 \\
\hline Finland & 1.01 & 1.12 \\
\hline France & 1.11 & 0.99 \\
\hline FYROM & 0.23 & 0.93 \\
\hline Germany & 1.11 & 1.09 \\
\hline Greece & 0.62 & 1.00 \\
\hline Hungary & 0.51 & 1.02 \\
\hline Ireland & 1.11 & 1.04 \\
\hline Italy & 1.00 & 0.88 \\
\hline Latvia & 0.40 & 1.07 \\
\hline Lithuania & 0.41 & 1.05 \\
\hline Luxembourg & 2.14 & 0.99 \\
\hline Malta & 0.84 & 0.93 \\
\hline Netherlands & 1.17 & 1.05 \\
\hline Poland & 0.38 & 1.10 \\
\hline Portugal & 0.77 & 0.72 \\
\hline Romania & 0.23 & 1.07 \\
\hline Serbia and Montenegro & 0.09 & 0.93 \\
\hline Slovakia & 0.43 & 1.05 \\
\hline Slovenia & 0.81 & 0.91 \\
\hline Spain & 0.87 & 0.90 \\
\hline Sweden & 1.12 & 1.21 \\
\hline Turkey & 0.25 & 0.71 \\
\hline
\end{tabular}


Table 3-Continued

\begin{tabular}{crr}
\hline \hline Country & PCGDP & Productivity \\
\hline United Kingdom & 1.10 & 1.06 \\
\hline
\end{tabular}

Table 4. Results of Calibration

\begin{tabular}{lrr}
\hline \multicolumn{1}{c}{ Variable } & May 2007 & Data \\
\hline & & \\
& 7.2 & 7.2 \\
Increase in NMS-10 Exports to EU-15 & & \\
(Percent of Exporter GDP) & 0.32 & 0.32 \\
EU-25 X/GDP & 20 & 20 \\
Percentage of Exporting Firms & 750 & 750 \\
Migrants to IRE, SWE, UK (000) & & \\
\hline
\end{tabular}

Table 5. Validation of Calibration Against 5-Year Increase in Exports to EU-15

\begin{tabular}{lrr}
\hline \hline \multicolumn{1}{c}{ Country } & $\begin{array}{c}\text { Actual } \\
\text { Value }\end{array}$ & $\begin{array}{c}\text { Predicted } \\
\text { Value }\end{array}$ \\
\hline & & \\
Cyprus & 0.9 & 4.4 \\
Czech Republic & 13.7 & 20.3 \\
Estonia & 18.2 & 24.2 \\
Hungary & 19.0 & 11.7 \\
Latvia & -8.2 & -5.4 \\
Lithuania & -5.4 & -6.3 \\
Malta & -6.5 & 0.0 \\
Poland & 2.0 & -1.1 \\
Slovakia & 17.6 & 23.6 \\
Slovenia & 5.0 & 14.2 \\
NMS-10 TOTAL & $\mathbf{7 . 2}$ & $\mathbf{7 . 2}$ \\
\hline
\end{tabular}


Table 6. Validation of Calibration Against Other Evidence

\begin{tabular}{lrr}
\hline \hline \multicolumn{1}{c}{ Variable } & May 2007 & BEJK 2003 \\
\hline & & \\
Exporter Relative Productivity (\%) & 120 & 133 \\
Exporter Relative Size (\%) & 257 & 560 \\
Exporter \% of Total Output & 41 & 60 \\
& & \\
MEMO: & & \\
Percentage of Profitable Firms & 201 &.. \\
Producer Relative Productivity (\%) & & \\
& May 2007 & AvW 2004 \\
& 48 & 71 \\
Average Trade Cost (\% of MC) & & \\
\hline
\end{tabular}


Table 7. Parameter Values

\begin{tabular}{|c|c|}
\hline Variable & Value \\
\hline \multicolumn{2}{|l|}{ Assigned } \\
\hline \multicolumn{2}{|l|}{ Assigned } \\
\hline$\rho$ & 0.75 \\
\hline$\sigma_{\phi_{f}}^{2}$ & 0.50 \\
\hline$\delta_{1}$ & 1 \\
\hline$\delta_{2}$ & 0.001 \\
\hline$\delta_{3}$ & 0.0001 \\
\hline$\delta_{4}$ & 0 \\
\hline$\eta$ & 100 \\
\hline$\theta$ & 0.01 \\
\hline threshold & 0.1 \\
\hline$\Omega$ & 0.11 \\
\hline$I$ & 4 \\
\hline Approximate Firms Per Industry & 10,000 \\
\hline \multicolumn{2}{|l|}{ Calibrated } \\
\hline$t_{1}$ & 0.26 \\
\hline$t_{2}$ & 0.26 \\
\hline$t_{3}$ & 0.26 \\
\hline$t_{4}$ & 0.26 \\
\hline$b_{1}$ & 0.31 \\
\hline$b_{2}$ & 0.31 \\
\hline$b_{3}$ & 0.31 \\
\hline$b_{4}$ & 0.31 \\
\hline$f c_{e}$ & 720 \\
\hline$\gamma$ & 0.0136 \\
\hline
\end{tabular}




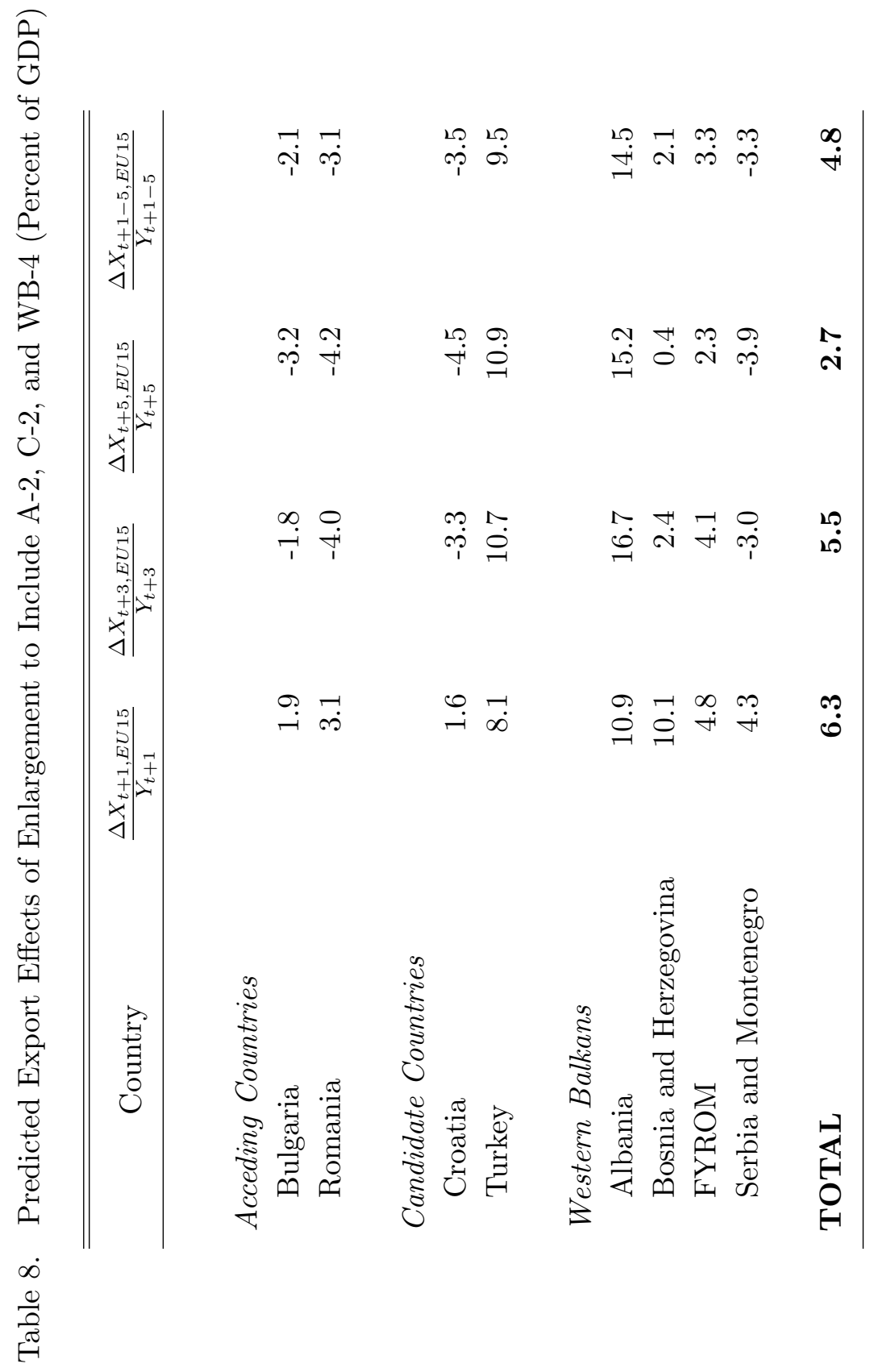




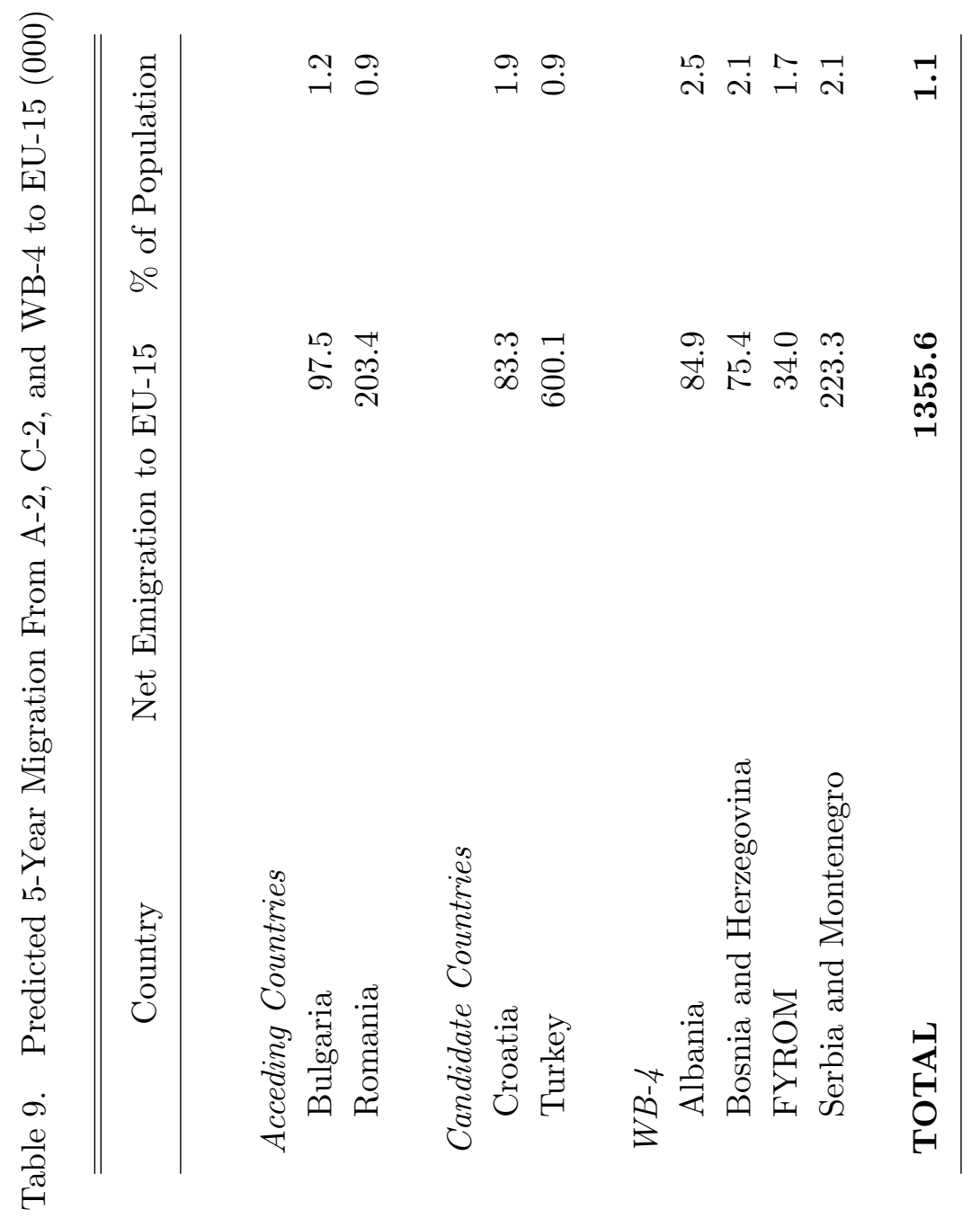




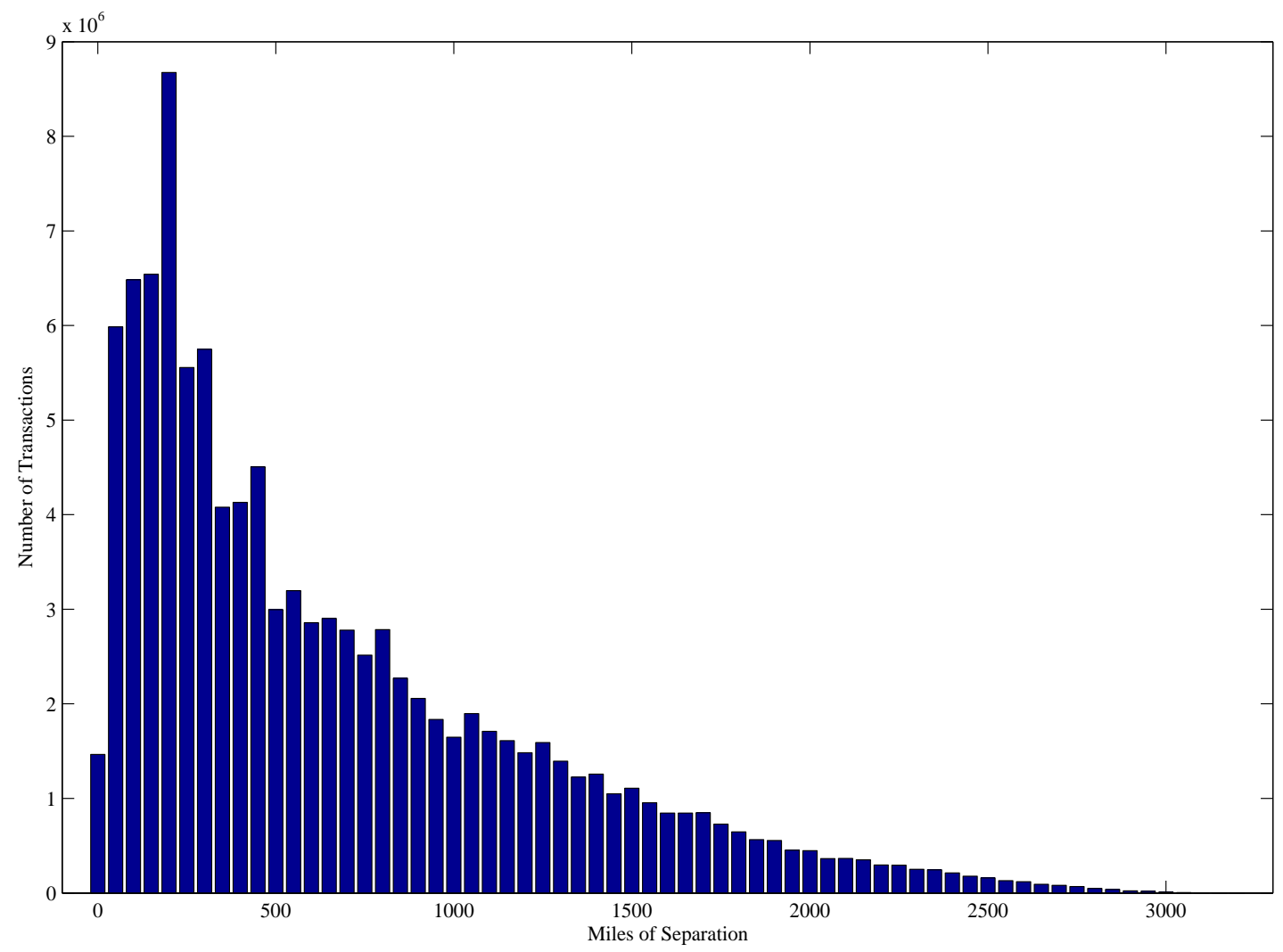

Fig. 6.- Transactions by Distance of Consumer from Producer (Approximate Statute Miles) 

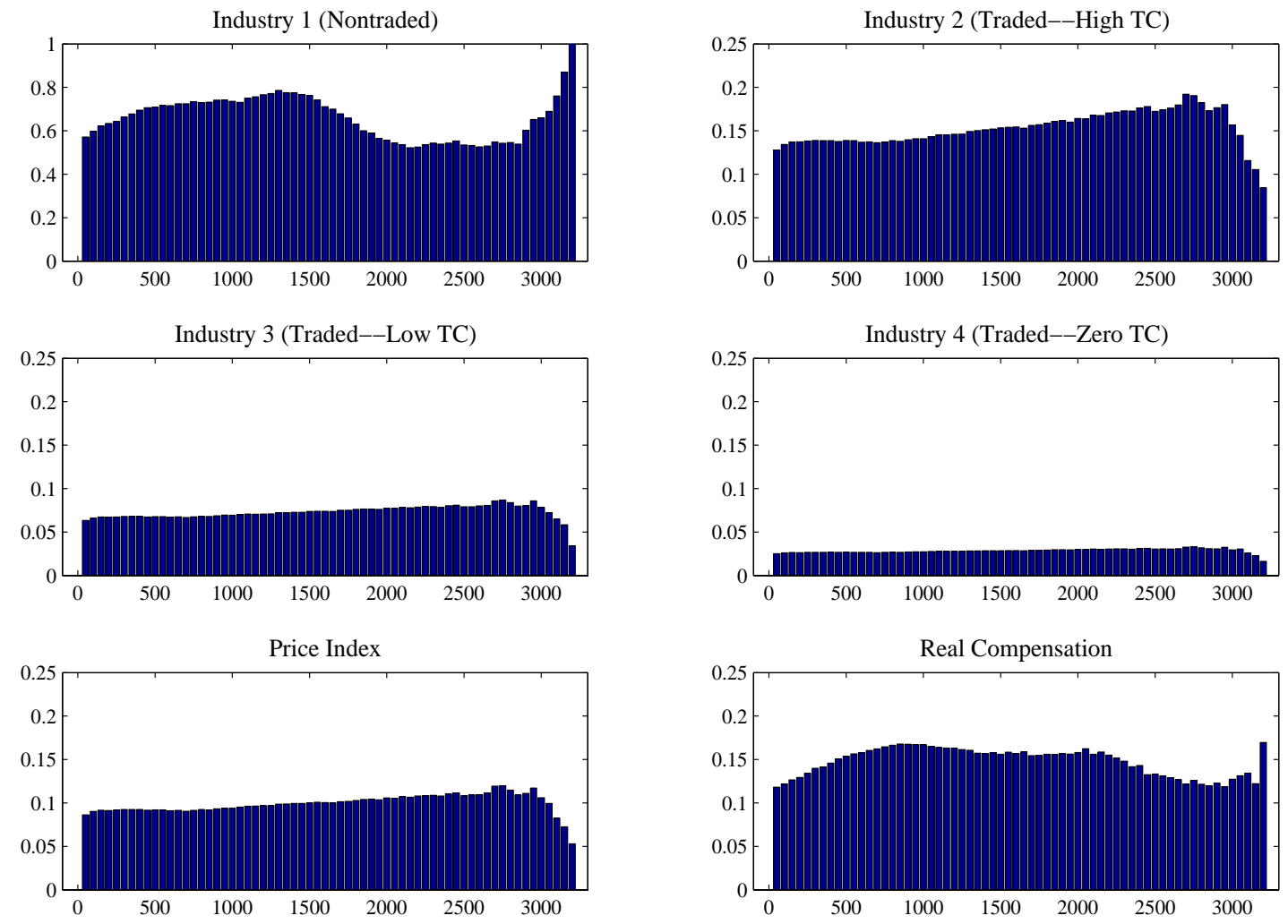

Fig. 7.- Log Price Differentials by Distance (Approximate Statute Miles) 


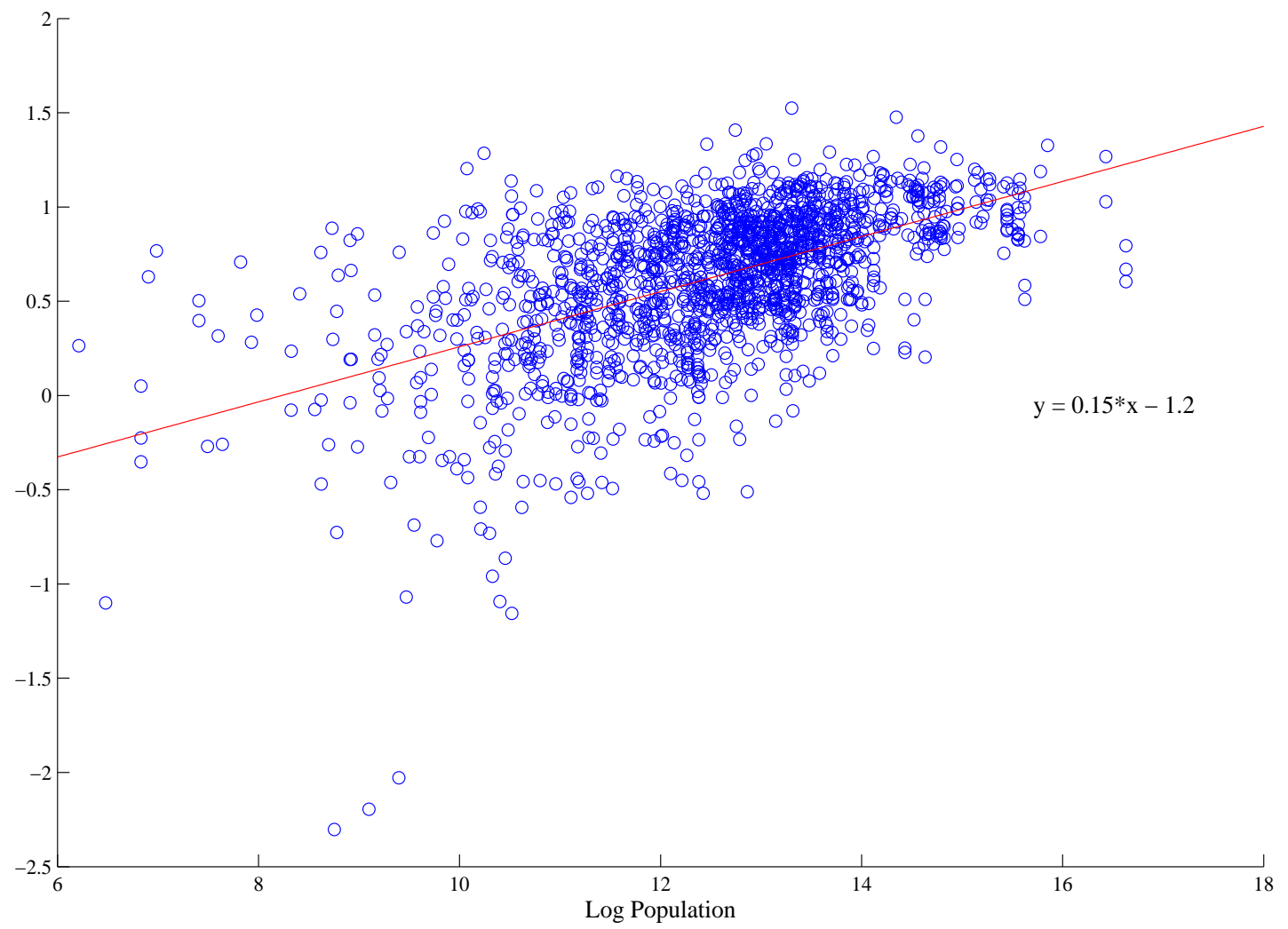

Fig. 8.- Log Productivity of Active Firms by Log Population of Firm Location 


\section{REFERENCES}

Anderson, James E. and van Wincoop, Eric. "Trade Costs." NBER Working Paper 10480, May 2004.

Baldwin, Richard. "The Eastern Enlargement of the European Union." European Economic Review, 1995, 39, 474-81.

Baldwin, Richard; Francois, Joseph F. and Portes, Richard. "The Costs and Benefits of Eastern Enlargement: The Impact on the EU and Central Europe." Economic Policy, April 1997, 21, 125-76.

Baldwin, Richard and Okubo, Toshihiro. "Heterogeneous Firms, Agglomeration and Economic Geography: Spatial Selection and Sorting." NBER Working Paper 11650, September 2005.

Barro, Robert J. and Lee, Jong-Wha. "International Data on Educational Attainment: Updates and Implications." mimeo, 2000.

Bernard, Andrew B. and Jensen, J. Bradford. "Exceptional Exporter Performance: Cause, Effect, or Both?" Journal of International Economics, February 1999, 47(1), pp. 1-25.

Bernard, Andrew B.; Eaton, Jonathan; Jensen, J. Bradford and Kortum, Samuel. "Plants and Productivity in International Trade." The American Economic Review, September 2003, 93(4), pp. 1268-90.

Bernard, Andrew B.; Redding, Stephen and Schott, Peter. "Comparative Advantage and Heterogeneous Firms." mimeo, 2005.

Caselli, Francesco. "Accounting for Cross-Country Income Differences." NBER Working Paper 10828, October 2004.

Chaney, Thomas. "Distorted Gravity: Heterogeneous Firms, Market Structure, and the Geography of International Trade." mimeo, 2005.

Directorate General for Economic and Financial Affairs. "The Economic Impact of Enlargement." Enlargement Papers, June 2001, 4.

Dixit, Avinash and Stiglitz, Joseph E. "Monopolistic Competition and Optimum Product Diversity." The American Economic Review, June 1977, 67(3), pp. 297-308.

Eaton, Jonathan and Kortum, Samuel. "Technology, Geography, and Trade." Econometrica, September 2002, 70(5), pp. 1741-79.

Eaton, Jonathan; Kortum, Samuel and Kramarz, Francis. "An Anatomy of International Trade: Evidence from French Firms." mimeo, 2004. 
Eaton, Jonathan; Kortum, Samuel and Kramarz, Francis. "Dissecting Trade: Firms, Industries, and Export Destinations." The American Economic Review, Papers and Proceedings May 2004, 94(2), pp. 150-54.

Eurostat Database. http://epp.eurostat.ec.europa.eu/portal/.

Fujita, Masahisa; Krugman, Paul and Venables, Anthony J. The Spatial Economy: Cities, Regions, and International Trade. Cambridge, MA: MIT Press, 1999.

Hanson, Gordon and Xiang, Chong. "The Home-Market Effect and Bilateral Trade Patterns." The American Economic Review, September 2004, 94(4), pp. 1108-29.

Hoekman, Bernard and Djankov, Simeon. "Determinants of the Export Structure of Countries in Central and Eastern Europe." The World Bank Economic Review, 1997, 11(3), pp. 471-87.

International Monetary Fund. Direction of Trade Statistics Yearbook, 2004.

International Monetary Fund. Direction of Trade Statistics Yearbook, 2000.

International Monetary Fund. Direction of Trade Statistics Yearbook, 1997.

Kaminski, Bartlomiej. "How Accession to the European Union Has Affected External Trade and Foreign Direct Investment in Central European Economies." World Bank Policy Research Working Paper 2578, April 2001.

Kohler, Wilhelm. "Eastern Enlargement of the EU: A Modeling Perspective" Keynote Address Delivered at the Annual Meeting of the Austrian Economic Association, Vienna, May 25-26, 2000 .

Kohler, Wilhelm and Keuschnigg, Christian. "An Incumbent Country View on Eastern Enlargement of the EU-Part 1: A General Treatment." Empirica, 2000, 27, pp. 325-51.

Kohler, Wilhelm and Keuschnigg, Christian. "Eastern Enlargement of the European Union: A Dynamic General Equilibrium Perspective", in: Harrison, et al., eds., Using Dynamic General Equilibrium Models for Policy Analysis, Amsterdam: Elsevier Science B.V. (Contributions to Economic Analysis, vol. 248), 2000, pp. 119-170.

Krugman, Paul. "Increasing Returns and Economic Geography." The Journal of Political Economy, June 1991, 99(3), pp. 483-99.

Krugman, Paul and Venables, Anthony J. "Globalization and the Inequality of Nations." The Quarterly Journal of Economics, November 1995, 110(4), pp. 857-80.

Melitz, Marc J. "The Impact of Trade on Intra-Industry Reallocations and Aggregate Industry Productivity." Econometrica, November 2003, 71(6), pp. 1695-1725. 
Pavcnik, Nina. "Trade Liberalization, Exit, and Productivity Improvements: Evidence from Chilean Plants." The Review of Economic Studies, January 2002, 69(1), pp. 245-76.

Redding, Stephen and Sturm, Daniel M. "The Costs of Remoteness: Evidence from German Division and Reunification." CEP Discussion Paper No 688, May 2005.

Redding, Stephen and Venables, Anthony. "Economic Geography and International Inequality." Journal of International Economics, 2004, 62, pp. 53-82.

Resmini, Laura "Economic Integration, Industry Location and Frontier Economies in Transition Countries." Economic Systems, 2003, 27(2), pp. 205-221.

Sachs, Jeffrey; Faye, Michael; McArthur, John and Snow, Thomas. "The Challenges Facing Landlocked Developing Countries." Journal of Human Development, March 2004, 5(1), pp. 31-68.

Tybout, James. "Plant- and Firm-Level Evidence on 'New' Trade Theories." NBER Working Paper 8418, August 2001.

United Nations Development Programme. Human Development Report 2002 New York, NY: UNDP, 2005.

Venables, Anthony, J. "Economic Integration and the Location of Firms." The American Economic Review, May 1995, 85(2), pp. 296-300. 